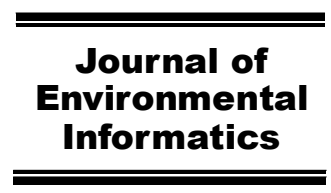

www.iseis.org/jei

\title{
Spatial Multicriteria Analysis for Siting Groundwater Polluting Industries
}

\author{
P. Negi ${ }^{*}$ and K. Jain \\ Department of Civil Engineering, Indian Institute of Technology (IIT) Roorkee, Roorkee 247 667, U.A., India
}

Received 9 July 2007; revised 25 January 2008; accepted 28 February 2008; published online 2 September 2008

\begin{abstract}
Industrialization has led to economic growth but along with it is also responsible for various environmental pollution problems. There are many studies which show that industrial pollution has badly affected the groundwater. Site suitability analysis before sitting industries can be a solution for sustainable industrial development. Therefore the idea of the present study is to utilize spatial multicriteria approach to find out suitable areas for groundwater polluting industries considering environmental as well as economic factors. The study is divided into three steps, environmental suitability analysis, socio-economic suitability analysis and then cross classification of two suitability maps which results in suitable site for groundwater polluting industries. In the suitability analysis, factors maps were standardize using fuzzy membership functions and factor weights were generated using Analytical Hierarchy Process (AHP). Further, the factors were aggregated using weighted linear combination (WLC) technique. The result shows that $36.91 \%$ of area is unsuitable for industrial sitting and the study area is suitable for medium and low water polluting industries and not suitable for heavy water polluting industries. Finally, it is concluded that spatial multicriteria decision making can be a powerful tool for preliminary Environmental Impact Assessment for sitting industries.
\end{abstract}

Keywords: Geographical Information System (GIS), site suitability, mutli-criteria analysis, Analytical Hierarchy Process (AHP), groundwater, pollution, industries

\section{Introduction}

Groundwater is a major source of drinking water in both urban and rural India. The annual water demand in India was $750 \mathrm{~km}^{3}$ for year 2000 and the country would require about $1050 \mathrm{~km}^{3}$ by the year 2025 because of increased demand of water required to grow more food grains for the increasing population, which is estimated to reach up to 1.25 billion by the year 2025 (Singhal, 2002; Musa, 2004). With the increasing demand for water, the importance of groundwater for the existence of human society cannot be overemphasized. Till recently it had been considered a dependable source of uncontaminated water, but now industrial, agricultural, waste disposal activities are resulting in degradation of groundwater quality which may lead to water crisis.

Industrialization, no doubt, contributes to economic growth but along with this it brings many environmental problems. Industrial developmental activities which can cause groundwater pollution are process water/effluent lagoons, tanks and pipeline leakage, accidental spillages, land discharge of effluent, landfill disposal residues and waste, well disposal of effluent and aerial fallout (Canter, 1996). Even various studies,

\footnotetext{
${ }^{*}$ Corresponding author. Tel.: +91 1332 285465; fax: +91 1332273560.

E-mail address: poonam.negi@gmail.com (P. Negi).
}

ISSN: 1726-2135 print/1684-8799 online

(C) 2008 ISEIS All rights reserved. doi:10.3808/jei.200800124 like Jagannadha et al. (1986), Chakraborti et al. (1998), Subba Rao et al. (1998), Olayinka, 2004, Mondal et al. (2005), Satyanarayana et al. (2005) etc., have shown that industrialization is playing major role in groundwater pollution. Chakraborti et al. (1998) reported high arsenic concentration in the urine of people who were drinking polluted groundwater in Calcutta. Kaplay and Patode (2004) studied the groundwater pollution due to industrial effluents at Tuppa, New Nanded area which was once blessed with abundant good quality groundwater during pre-industrial period but with rapid industrialization, the groundwater pollution also increased in Tuppa. The final industrial products in this area are steel sheets, galvanized sheets (for washing of these sheets hydrochloric acid is generally used), fertilizers fabrication, textiles, and reinforced cement concrete pipes etc. The groundwater analysis of this area has shown that it contains high concentrations of sulphates and chlorides which have increased acidity in groundwater. Mondal et al. (2005) found that the quality of groundwater near Dindigul area was deteriorated mainly due to extensive use of salt in the leather industries. Satyanarayana et al. (2005) described how rapid industrialization has contributed to serious groundwater pollution problems in Patancheru town in Andhra Pradesh. This study has shown that the concentration of trace elements like Manganese, Nickel, Zinc and Chromium was high in groundwater. Further, industrialization has polluted the groundwater to such an extent that it is not usable for domestic and agriculture purposes. Even the drinking water in Patancheru is provided by tankers and pipelines from faraway 
places. Thus, the quality of groundwater is severely affected by the discharge of industrial effluents.

The various methods for groundwater remediation are soil vapour extraction, natural attenuation, pumping and treating of groundwater, in situ bioremediation, in situ groundwater treatment (neutralization or biodegradation), or a combination of methods. In some cases, like karst environments, the remediation may be difficult or impractical because of the difficultties of defining and intercepting groundwater flow paths. Therefore, the groundwater remediation is an expensive and slow process. The prevention of groundwater pollution is the key to efficient and effective environmental management (Agarwal, 1996). Thus, to protect groundwater resources, areas prone to contamination by human activity need to be delineated. The injudicious siting of industry is one of the factors which are responsible for such pollution problems. These problems can be avoided at planning stage, if industrial locations are based on environmental considerations (CPCB Report, 1997). The aim of present study is to identify the suitable area for setting up groundwater polluting industries. The study is carried out in three steps: (1) Suitability analysis considering environmental factors; (2) Suitability analysis considering socio-economic factors; (3) Finally, suitability for groundwater polluting industries was obtained by combining two suitability maps.

Ian McHarg (1969) invented suitability analysis, by superimposing different maps so that their spatial intersection (relationships) can be used in making land use decisions. Suitability assessment is identification of the most appropriate location for the specific use. In this process, the entire study area is mapped into a suitability index (Joerin et al., 2001). The purpose of land suitability analysis is to predict the inherent capacity of a land unit to support land use for a long period of time without deterioration, in order to minimize environmental and socio-economic impacts. It enables environmental managers and planners to analyze the interactions among three types of factors: location, development actions, and environmental elements (Collins et al., 2001). Suitability evaluation is a context-dependent concept in which the attributes of a site are compared against the desired attributes of an ideal site for a specific purpose (Jiang et al., 2000; Stoms et al., 2000). It depends on many factors like soil type, climate, landuse, road accessibility etc.; therefore it is a multi-criteria problem (Mendoza, 1997; Malczewski, 1999). Multi-criteria analysis combines a set of criteria to achieve a single composite basis for a decision according to a specific objective (Eastman et al., 1995). The advantage of multi-criteria analysis is that it provides a flexible way of dealing with qualitative multi-dimensional environmental effects of decisions (Malczewski, 1999). There is no independent measure of suitability that can be observed directly, and thus no ground truth for validating spatial models. Instead, experts define the most desirable attributes in terms of measurable factors, the optimum values of those factors, and their relative importance weights in a multi-criteria evaluation (Jiang and Eastman, 2000). The conventional multi-criteria evaluation techniques assume that the study area is spatially homogenous. This, however, is unrealistic when suitability analysis is considered because the evaluation criteria vary across the space (Malczewski, 1999). Therefore, GIS and multi-criteria evaluation are integrated to add geographical component in it. This is called as spatial (GIS based) multicriteria analysis. The spatial multi-criteria analysis involves evaluation of geographical inputs based on the criteria values and the decision maker's preferences with respect to a set of evaluation criteria.

The requirement of multi criteria analysis is that the values contains in the various factor maps should be transformed to comparable scale. The factors (like road proximity, urban proximity etc.) were standardized using fuzzy membership functions because when compared with linear scaling, standardization using fuzzy set membership represents a specific relation between the criterion (factor) and decision set (suitability). The fuzzy logic bridges gap between boolean assessment and continuous scaling in weight linear combination (Jiang and Eastman, 2000). Any decision is based on the criteria/factors of varying importance and to express the relative importance of the criteria, the weighting of criteria came into existence. The various methods of weight assessment in multi criteria analysis are rating, ranking, pairwise comparison (AHP) etc. Thomas (2002) used ordinal ranking for development of GIS based Decision support system for Brownfield redevelopment. The disadvantage of ordinal ranking is that they cannot be aggregated in any meaningful way (Malczewski, 2004). Rating methods require the decision maker to estimate weights on the basis of a predefined scale (Malczewski, 1999). Inyang et al. (2003) used rating method for indexing environmental sensitivity and pollution potential. The rating and ranking methods lack theoretical foundation; hence it is difficult to justify the weights assigned to criteria (Malczewski, 1999). Therefore, pairwise comparision (AHP) was used for the determination of the criteria weights as it statistically computes the distribution of weights from a given set of relative importance ranking of the criteria (BanaiKashani, 1989). The process of combining criteria into a single composite index is called as spatial modeling (Eastman, 2003). The weighted linear combination (WLC) technique was used to obtain suitability map. It is easy and can be implemented in both raster and vector GIS environment (Malczewski, 1999). Lwasa (1998) used WLC method for siting residential housing for urban land use planning in Kampala and Geneletti (2004) used WLC technique for assessing the ecosystems. In the present study, fuzzy functions were used to standardize proximity criteria (factors) and factor weights were generated using Analytical Hierarchy Process (AHP) and the suitability was calculated using weighted linear combination (WLC) technique.

\section{The Study Area}

Uttaranchal is the $27^{\text {th }}$ state of the India and was formed on November 9, 2000. To have strong economy, the state government is concentrating on industrial development. The development should be in such a way that the desired socio-economic progress and safe guarding of environment and maintaining good quality living conditions are obtained simulta- 
neously. The conventional method for industrial location is manual grid overlay. It is time taking procedure and is criticized when fast decision making is required in planning. Therefore, GIS based/ spatial multicriteria analysis is utilized to identify the suitable area for siting industries, which will be useful for decision makers and government officials who are involved in industrial planning at regional scale. Haridwar district of Uttaranchal has been taken as the study area for the present study (Figure 1). Geographically, it lies between latitudes $29^{\circ} 30^{\prime}$ to $30^{\circ} 45^{\prime} \mathrm{N}$ and longitudes $77^{\circ}$ to $78^{\circ} 45^{\prime} \mathrm{E}$ with the total area of approximately $2360 \mathrm{sq} . \mathrm{km}$ and covers the SOI Toposheets No. $53 \mathrm{~F} / 16,53 \mathrm{~J} / 4,53 \mathrm{G} / 9,53 \mathrm{G} / 13,53$ $\mathrm{G} / 14,53 \mathrm{~K} / 1,53 \mathrm{~K} / 2,53 \mathrm{~K} / 5,53 \mathrm{~K} / 9$ on the scale of $1: 50,000$. The study area is a part of typical warm humid climate region. The climate is generally cold in winter and hot in summer with temperature ranging from $5{ }^{\circ} \mathrm{C}$ to $45^{\circ} \mathrm{C}$. Precipitation takes place in the monsoon season, which lasts from June to September. The average rainfall in this area is about $1050 \mathrm{~mm}$. Haridwar lies in the Indo-Gangetic Plain, which is mainly composed of alluvium sediments transported from the Himalayan Rivers. The rivers flowing in this area are Ganga, Banganga, Solani, Ranipur Rao, Rawli Rao.

\subsection{Inputs Layers}

The various input data and their sources is mentioned in the Table 1.The inputs (criteria) were divided into constrains and factors.

\subsubsection{Constrains}

Constraint is the area which was excluded from the suitability analysis like buffers zones for roads, flood, forests etc. as mentioned in the rules and regulations for industrial siting.

\subsubsection{Factors}

Evaluation criteria are called factors. Following are the factors considered for the study.

a) Environmental Criteria

Water Table: Water table is an important parameter in assessing the risk of groundwater contamination via surface pollutants (Simsek et al., 2006). It determines the depth of material through which a contaminant must travel before reaching the aquifer (Canter, 1996). It gives idea of the minimum distance that a pollutant has to travel to reach the saturated

Table 1. Various Factors \& Constrains Used in the Present Analysis and its Data Source

\begin{tabular}{|c|c|c|c|}
\hline & Criterion ( Input) & Constrain / Factor & Description / Data Source \\
\hline 1 & Forest Boundary & Constrain & $\begin{array}{l}\text { No forest land shall be converted into non-forest activity for the } \\
\text { sustenance of the industry. [Forest Conservation Act, 1980. } \\
\text { Environment (Siting for Industrial Projects) Rules, 1999] }\end{array}$ \\
\hline 2 & $\begin{array}{l}500 \mathrm{~m} \text { buffer of National } \\
\text { Highway / railway lines }\end{array}$ & Constrain & $\begin{array}{l}1 / 2 \mathrm{~km} \text {. from highway and railway [(Industries Development and } \\
\text { Regulation Act, Environment (Siting for Industrial Projects) Rules, } \\
\text { 1999] }\end{array}$ \\
\hline 3 & $\begin{array}{l}500 \mathrm{~m} \text { buffer of River } \\
\text { Ganga }\end{array}$ & Constrain & $\begin{array}{l}1 / 2 \mathrm{~km} \text {. from Flood Plain of the Riverine Systems [Industries } \\
\text { (Development and Regulation) Act, Environment (Siting for } \\
\text { Industrial Projects) Rules, 1999] }\end{array}$ \\
\hline $4^{\wedge}$ & Land Use Land Cover & Factor & $\begin{array}{l}\text { IRS P6 - AWiFS Data-20 } 0^{\text {th }} \text { Oct. 2004, Row 51, Path 96. Bands B2 } \\
0.52-0.59, \text { B3 0.62-0.68, B4 0.77-0.86 and B5 1.55-1.70, Spatial } \\
\text { Resolution 56m. Source: NRSA - Hyderbad }\end{array}$ \\
\hline $5^{*}$ & Water Table depth & Factor & $\begin{array}{l}\text { Source: Groundwater Resource from District Resource Map, } \\
\text { Geological Survey of India. Scale 1:250000 }\end{array}$ \\
\hline $6^{*}$ & Soil map & Factor & $\begin{array}{l}\text { Source: (NBSS\&LUP) National Bureau of Soil Survey \&Land Use } \\
\text { Planning, Regional Centre Delhi, scale 1:500000 }\end{array}$ \\
\hline $7 *$ & Slope & Factor & Source: Survey of India-Toposheets Scale 1:50000 \\
\hline $8^{\wedge}$ & Population Density & Factor & Source: District Census Data 2001 \\
\hline 9* & $\begin{array}{l}\text { Forest Area \& Proximity } \\
\text { to Forest }\end{array}$ & $\begin{array}{l}\text { Constrain \& Fuzzy } \\
\text { factor }\end{array}$ & $\begin{array}{l}\text { Source: State of Forest Report 2003, Forest Survey of India } \\
\text { Pathri Reserved Forest, Siwalik Reserved Forest, Dolkarini } \\
\text { Reserved Forest are in the study area }\end{array}$ \\
\hline $10 * *$ & Highways Proximity & Fuzzy factor & $\begin{array}{l}\text { Source: SOI- Toposheets, updated from ASTER L1-B data (Dated: } \\
21 \text { feb-2005) }\end{array}$ \\
\hline $11 * *$ & $\begin{array}{l}\text { Other metalled roads } \\
\text { Proximity }\end{array}$ & Fuzzy factor & $\begin{array}{l}\text { Source: SOI- Toposheets, updated from ASTER L1-B data (Dated: } \\
21 \text { feb-2005) }\end{array}$ \\
\hline $12 * *$ & $\begin{array}{l}\text { Existing industries / } \\
\text { Industrial area Proximity }\end{array}$ & Fuzzy factor & Source: Toposheets, State Pollution Control Board, Uttarakhand \\
\hline $13^{* *}$ & Railway Proximity & Fuzzy factor & $\begin{array}{l}\text { Source: SOI- Toposheets, updated from ASTER L1-B data (Dated: } \\
21 \text { feb-2005) }\end{array}$ \\
\hline $14^{* *}$ & Urban Centers Proximity & Fuzzy factor & $\begin{array}{l}\text { Source: SOI- Toposheets, updated from ASTER L1-B data (Dated: } \\
21 \text { feb-2005) }\end{array}$ \\
\hline
\end{tabular}

* Factors for Env. Suitability; ** Factors for Socio-eco. Suitability; ^ Factors used in both. 
zone and is proportional to the capability of attenuation from pollutants. Shallow groundwater table is considered more vulnerable than the deep one. The groundwater table map was categoried into three classes as shown in Table 2.

Drainability and Soil: Drainability is used to describe the relative rapidity and extent of removal of water in the soil which is dependent upon the soil permeability. The soil permeability is determined by soil texture (Burden and Sims, 1999). The soil has a significant impact on the amount of recharge, which can infiltrate into the groundwater and hence, influences the ability of contaminants to move vertically into the vadose zone. The various drainage classes found in the Haridwar district are imperfectly drained, well drained, somewhat excessively drained and excessively drained. Since, the study area is part of Indo-Gangetic Plain, which is mainly composed of alluvium sediments transported from the Himalayan Rivers. The soil types found in this area are sandy, loam and silt loam (Agarwal et al., 2000; Musa, 2004).

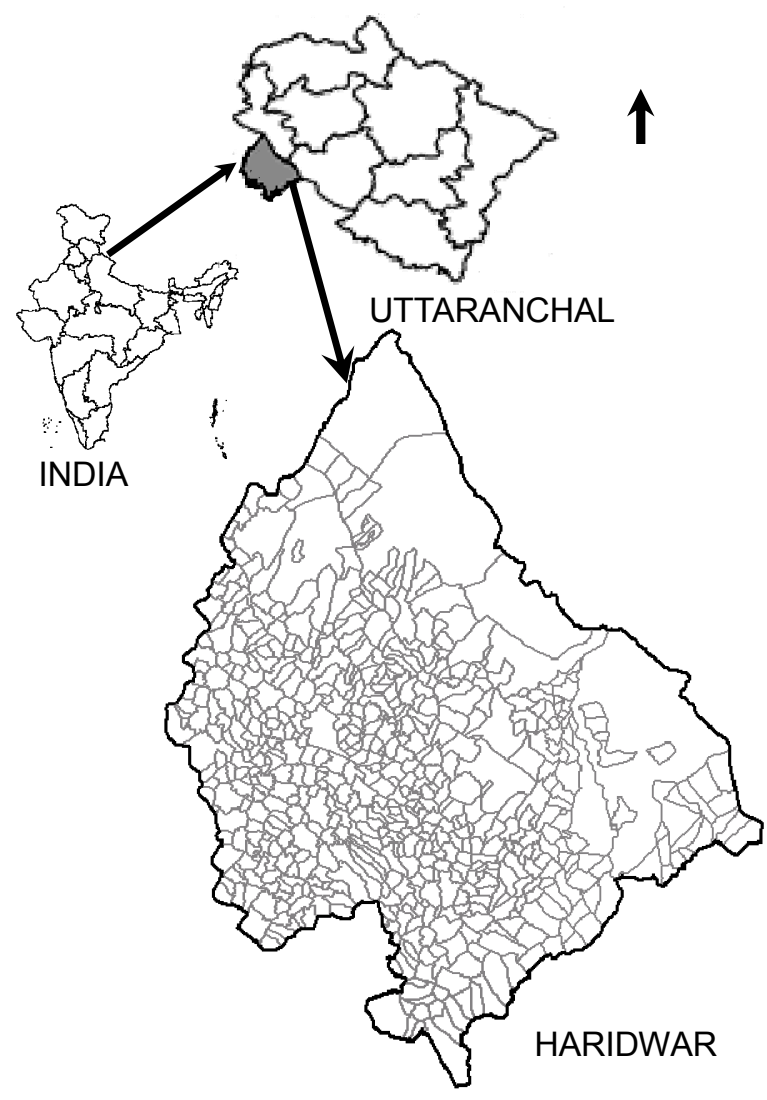

Figure 1. The location of the study area "Haridwar District".

Slope Map: Slope refers to the variability of the land surface and gives an idea whether the pollutant will run off or remain on the surface in one area long enough to infiltrate. Area with low slope tends to retain water longer. This allows greater infiltration of recharge water and greater potential for contaminant migration. Area with steep slopes having large amount of runoff and smaller amount of infiltration, are less vulnera- ble to groundwater contamination. The slope map is divided into following classes:

- Steep slope $\left(>15^{\circ}\right)$;

- Moderate slope $\left(<15^{\circ} \mathrm{deg}\right)$;

- Gentle slope $\left(<5^{\circ} \mathrm{deg}\right)$;

- Flat $\left(0^{\circ} \mathrm{deg}\right)$.

Strong (1988) considered land less than 2\% slope for industrial site selection as greater slope will require digging or filling for site preparation.

Land Use Land Cover (LULC): The knowledge of land use and land cover is important for land planning and management activities and it is considered as an essential element for modeling and understanding real world problems (Lillsand and Kiefer, 2000; Jenson, 2004). AWIFS data which was acquired on $20^{\text {th }}$ Oct. 2004 was used to generate land use land cover map. Supervised classification was done using maximum likelihood classifier to classify satellite data into various land use classes. The obtained LULC map was then reclassified into 10 classes (very dense vegetation, dense vegetation, river, canal, urban, rural settlements, sand, wetland, thin and sparse vegetation).

Population Density: Lower population density is considered more suitable than higher population density since the cost of land, property and effects on population decreases with decreasing density (Geol, 1992). The thematic map of population density was categorized in four classes: high density, medium density, low density and very low density.

Forest Proximity: Forests are species-rich ecosystems supporting a wide array of taxa from numerous groups ranging from birds and canopy arthropods to soil microbes (Lindenmayer, 1999). The preservation of biodiversity is essential for the sustainable development. Hence, if the area is richer is forest reserves, then it is less suitable for siting industries.

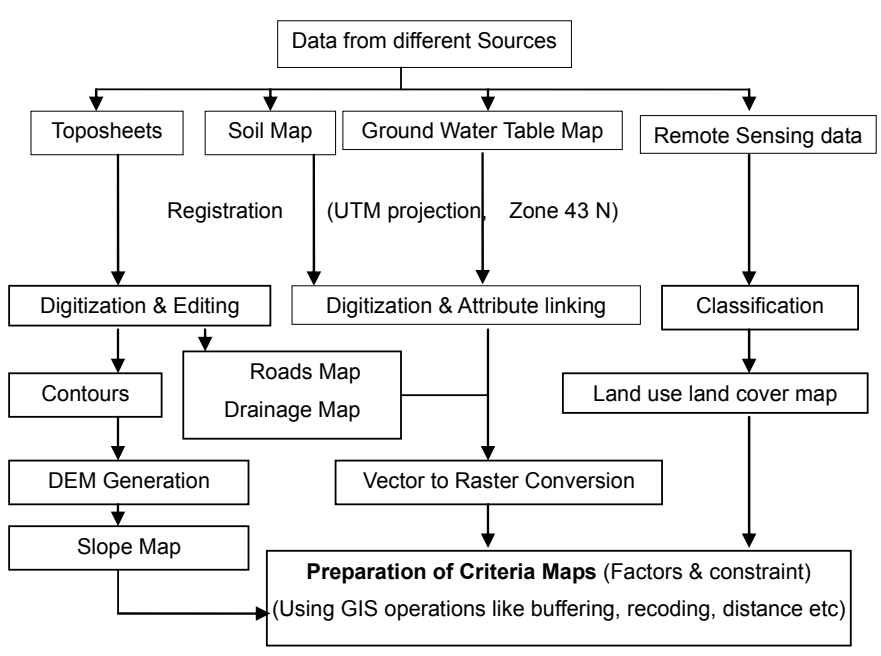

Figure 2. Methodology for preparation of criteria maps.

b) Other Important Criteria

The other dominant factors for industrial siting are accessibili- 


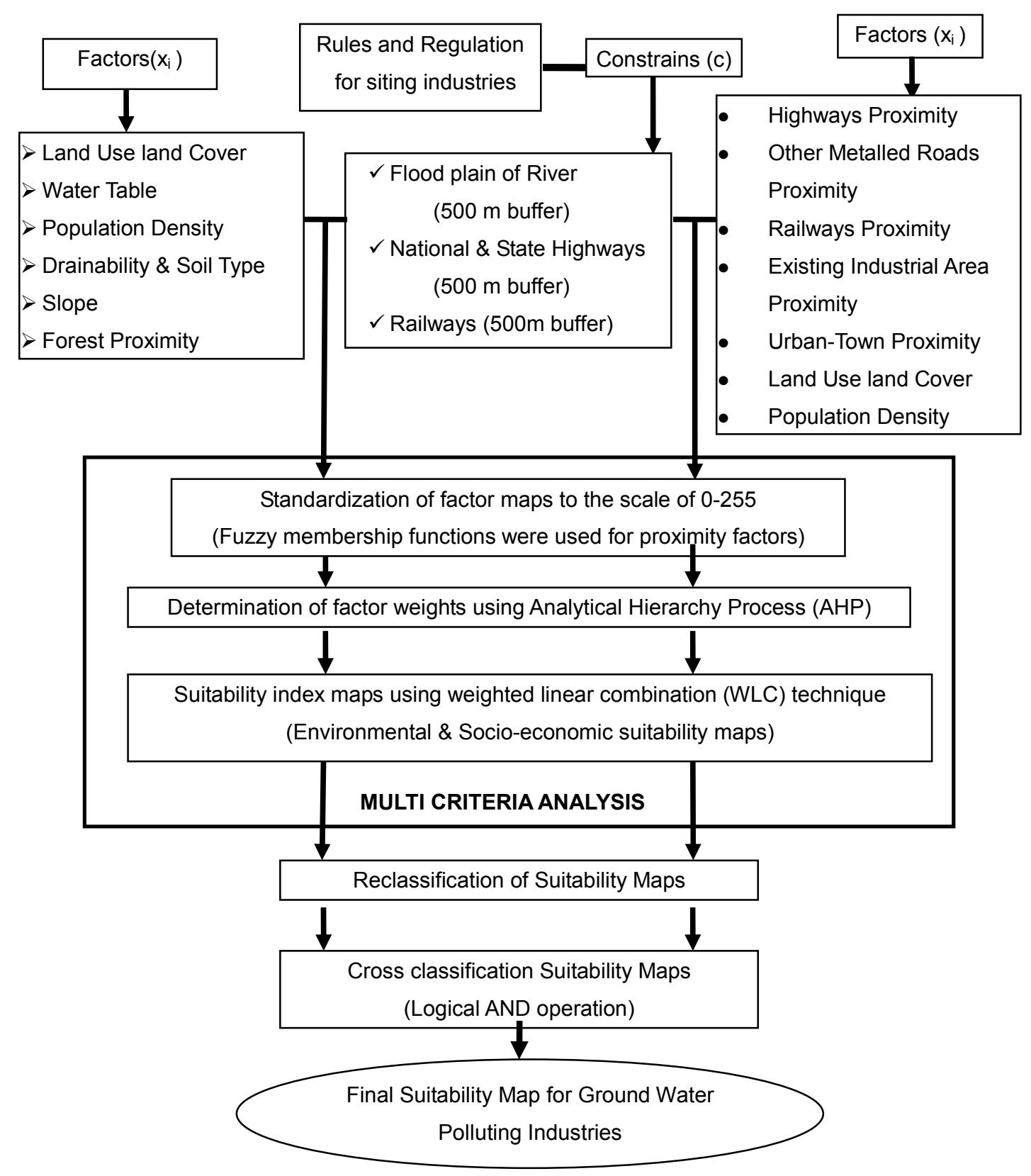

Figure 3. Methodology for the suitability analysis of siting groundwater polluting industries.

ty to markets, labor, raw materials, and transportation which have been considered as socio-economic factors.

Proximity to Transportation Facility: Cost of raw material transportation, cost of finished goods transportation etc. are dependent on the proximity to transportation facility. Transportation network bears the greatest importance in the site selection process (Strong, 1988). Not only this, the mode of transportation is also important. Therefore the transportation criterion is divided into 3 categories: National Highways proximity, metalled roads proximity and railways proximity. Strong (1988) mentioned that the highways are used $75 \%$ of the time while rail is used only $22 \%$ for industrial purposes. Therefore highways are given more importance than other mode of transportation.

Proximity to Urban-Town Centers: The idea of taking proximity to urban-town centers is to have provision of infrastructure, markets, ancillary services provided by urban centers, labor and raw materials requirement etc.

Proximity to Existing Industrial Area: Closeness to other industries, availability of utilities and lending institutions (such as banks etc.) were the criteria to take proximity to existing industrial area as an input layer. 


\section{Methodology}

The data from different sources, as mentioned in Table 1, was converted into digital format. Then, it was registered in UTM (zone $43 \mathrm{~N}$ ) projection system. The flowchart showing preparation of criteria maps is given in Fig. 2. The preparation of criteria maps include digitization, editing, attribute linking, interpolation for DEM generation, classification and vector to raster conversion. The various GIS operations like recoding, distance, and buffering etc. were also used.

The aim of the study is to minimize the environmental impacts of groundwater polluting industries by considering environmental criteria as well as other important socio-economic criteria like proximity to transportation, urban centers etc. for selecting suitable site for groundwater polluting industries. The study has been carried out in three steps after preparation of criteria maps:

- Determination of suitability according to environmental factors;

- Determination of suitability according to socio-economic factors;

- Cross classification of two suitability maps.

The flowchart in Fig. 3 displays the methodology for the suitability analysis of siting groundwater polluting industries.

\subsection{Standardization of Factor Maps}

Standardization is necessary to transform the disparate measurement units of the factor maps into comparable values. The factors were standardized to a byte-level range of $0 \sim 255$, which provides the maximum differentiation possible while analyzing data in byte type. The proximity factors (such as road proximity, rail proximity, and forest proximity) were standardized using fuzzy membership functions because fuzzy is applied to the data where boundaries are not sharply defined. The representation of continuous scaling is accurate in fuzzy set and the fuzzy algorithm allows decision makers to choose the membership functions that best represent their data (Jiang and Eastman, 2000; Morris and Jankowski, 2001). The GIS software like IDRISI have these algorithms, which allows the decision maker to interactively choose an algorithm that best helps them to make decisions (Morris and Jankowski, 2001; Eastman, 2003). Most commonly used monotonically increasing or decreasing sigmoidal (s-shaped) fuzzy functions were used in the study (Eastman, 2003). The sigmoidal membership function can be specified by four paprmeters: a - membership rises above zero; $b$ - membership becomes 1 ; $c$ - membership falls below 1; $\mathrm{d}-$ membership becomes zero. It is expressed as:

$\mu(x)=\cos ^{2} \alpha$

where $\alpha=\{[1-(x-a)] / b-a] \cdot \Pi / 2$; when $x>b, \mu(x)=1$ (for monotonically increasing function), or $\alpha=[(x-c) /(d-$ $c)$ ] $\Pi / 2$; when $x<c, \mu(x)=1$ (for monotonically decreasing function).

\subsection{Weights between Factors}

AHP technique was used to produce weights for various factors used in suitability analysis. It is pair wise comparison method developed by Saaty in1980. AHP provides a hierarchical structure that allows one to organize the relationship of factors in a suitability analysis (Reza Banai, 1989). It takes as an input the pairwise comparison and produces the relative weights as output. In this method, the weights are calculated by normalizing the eigenvector associated with the maximum eigenvalue of the ratio matrix. A rating scale of 1 to 9 is generally used to reflect the relative preference of one factor over another in pairwise comparison (Reza Banai, 1989; Malczewski J, 1999). Siddiqui et al. (1996) applied AHP technique on a spatial problem of landfill siting and called it as Spatial-AHP.

\subsection{Spatial Modeling}

Here, Weighted Linear Combination technique was used for solving multi-attribute decision making (Carver, 1991; Malczewski, 1999):

$S=\left(\Sigma w_{i} x_{i}\right) \Pi C_{i}$

where $S=$ suitability index/values; $\mathrm{w}_{\mathrm{i}}=$ weight of factor $i ; x_{i}=$ attribute score of factor $i ; \Pi=$ product; $C_{i}=$ constraints.

The environmental impact score of the low, medium and high groundwater polluting industries was 3,6 , and 8 (out of 10) based on the survey opinion. The impact score is directly related to the suitability values (Table 7). For example, the high groundwater polluting industries requires high suitability values so that site can bear its impact. Therefore, the resulted suitability index was reclassified into four classes: not suitable, low suitability, moderate suitability and high suitability having suitability values $0 \sim 77,78 \sim 153,154 \sim 204$ and $205 \sim$ 255 , respectively. The environmental and socio-economic reclassified maps were cross tabulated to obtain final suitability map.

\section{Result Analysis}

Table 2. Various Fuzzy Membership Functions Used to Scale Proximity Maps

\begin{tabular}{llll}
\hline $\begin{array}{l}\text { Factors } \\
\text { Proximity to) }\end{array}$ & $\begin{array}{l}\text { Function } \\
\text { Shape }\end{array}$ & $\begin{array}{l}\text { Function } \\
\text { Type }\end{array}$ & Control Points \\
\hline Forest & MI $^{*}$ & Sigmodial & $\mathrm{a}=500 \mathrm{~m} ; \mathrm{b}=5000 \mathrm{~m}$ \\
Highway & MD & $\begin{array}{c}\text { Sigmodial } \\
\text { Other Roads }\end{array}$ & $\mathrm{c}=500 \mathrm{~m} ; \mathrm{d}=7000 \mathrm{~m}$ \\
Railways & MD & Sigmodial & $\mathrm{c}=500 \mathrm{~m} ; \mathrm{d}=3000 \mathrm{~m}$ \\
Existing & SD & Sigmodial & $\mathrm{c}=500 \mathrm{~m} ; \mathrm{d}=3000 \mathrm{~m}$ \\
$\begin{array}{l}\text { Industrial area } \\
\text { Urban area }\end{array}$ & MD & Sigmodial & $\mathrm{c}=5000 \mathrm{~m} ; \mathrm{d}=10000 \mathrm{~m}$ \\
\hline
\end{tabular}

*MI: Monotonically Increasing; MD: Monotonically Decreasing. 
Table 3. Pairwise Comparison and Weights of Factors for Environmental Suitability

\begin{tabular}{lccccccc}
\hline & Forest Proximity & Population & Drainability/ Soil & LULC & Slope & Water Table & Weights \\
\hline Forest Proximity & 1 & $1 / 7$ & $1 / 5$ & $1 / 5$ & $1 / 3$ & $1 / 7$ & 0.0324 \\
Population & 7 & 1 & $1 / 3$ & $1 / 2$ & 3 & $1 / 5$ & 0.1414 \\
Drainability/ Soil & 5 & 3 & 1 & 1 & 3 & 1 & 0.2391 \\
LULC & 5 & 2 & 1 & 1 & 5 & 1 & 0.2140 \\
Slope & 3 & $1 / 3$ & $1 / 3$ & $1 / 5$ & 1 & $1 / 5$ & 0.0608 \\
Water Table & 7 & 5 & 1 & 5 & 1 & 0.3123 \\
\hline
\end{tabular}

Table 4. Pairwise Comparison and Weights of Factors for Economic Suitability

\begin{tabular}{lcccccccc}
\hline Proximity & $\begin{array}{c}\text { Existing } \\
\text { Industries } \\
\text { Proximity }\end{array}$ & $\begin{array}{c}\text { Railway } \\
\text { Line } \\
\text { Proximity }\end{array}$ & $\begin{array}{c}\text { Metalled } \\
\text { Roads } \\
\text { Proximity }\end{array}$ & $\begin{array}{c}\text { National } \\
\text { Highways } \\
\text { Proximity }\end{array}$ & $\begin{array}{c}\text { Urban Town } \\
\text { Proximity }\end{array}$ & LULC & $\begin{array}{c}\text { Popu. } \\
\text { Density }\end{array}$ & Weights \\
\hline $\begin{array}{l}\text { Existing } \\
\text { industries }\end{array}$ & 1 & $1 / 5$ & $1 / 5$ & $1 / 9$ & $1 / 3$ & $1 / 3$ & $1 / 3$ & 0.0321 \\
$\begin{array}{l}\text { Railway line } \\
\text { Metalled }\end{array}$ & 5 & 1 & 1 & $1 / 3$ & 1 & 1 & $1 / 3$ & 0.1041 \\
$\begin{array}{l}\text { Roads } \\
\text { National }\end{array}$ & 5 & 1 & 1 & $1 / 3$ & 1 & 3 & 1 & 0.1384 \\
$\begin{array}{l}\text { Highways } \\
\text { Urban Town }\end{array}$ & 3 & 3 & 1 & 1 & 1 & 5 & 3 & 1 \\
$\begin{array}{l}\text { LULC } \\
\text { Population }\end{array}$ & 3 & 1 & $1 / 3$ & $1 / 3$ & $1 / 3$ & 1 & 1 & 0.3296 \\
Density & 3 & 3 & 1 & 1 & $1 / 3$ & 1 & 1 & 0.1630 \\
\hline
\end{tabular}

Table 5. Summary of Environmental and Economic Suitability

\begin{tabular}{cccccc}
\hline Class & $\begin{array}{c}\text { Suitability } \\
\text { classes }\end{array}$ & $\begin{array}{c}\text { Environmental Suitability } \\
(\text { area in sq. km) }\end{array}$ & $\begin{array}{c}\text { Environmental } \\
\text { Suitability (area in \%) }\end{array}$ & $\begin{array}{c}\text { Economic Suitability } \\
(\text { area in sq. km) }\end{array}$ & Economic Suitability (area in \%) \\
\hline 1 & $\begin{array}{c}\text { Not } \\
\text { Suitable } \\
\text { Low } \\
\text { Suitability } \\
\text { Medium } \\
\text { Suitability } \\
\text { High }\end{array}$ & 858.47 & 36.91 & 1123.23 & 48.29 \\
3 & 691.91 & 29.75 & 752.22 & 32.34 \\
4 & 774.80 & 33.31 & 117.18 & 5.33 \\
\hline Suitability & 0.68 & $0.03 \%$ & 2325.83 & $100 \%$ \\
\hline
\end{tabular}

Table 2 displays the fuzzy membership functions, which were used in the scaling of factors. The pairwise comparison matrix of factors for suitability analysis and their AHP weights are show in Table 3 and Table 4.

Weighted linear combination technique resulted in suitability index maps which are shown in Figures 4 and 5. These suitability index maps were then reclassified as shown in Figures 6 and 7. The final suitability map was the outcome of cross tabulation of environmental and socio-economic reclassified maps (Figure 8). The summary of both the reclassified maps and the final suitability map are shown in Tables 5 and 6, respectively.

Table 5 shows that the area for highly suitable class is 5\% when economic factors are considered and as per environmental criteria the study area is hardly suitable for highly polluting industries like Oil Refinery, Petrochemicals, Integrated
Iron \& Steel, Thermal Power Plant, Fertilizer, Copper Smelter, Dye \& Dye Intermediates, Pesticides, Leather, Textile, Pharmaceuticals, Pulp \& Paper (Agro based), Man Made Fiber (Synthetic and Semi Synthetic), Electro-Plating, Lead Smelting, Paint, Inorganic and toxic Organic Chemicals, Alcohol, and Distillery. It also shows that environmentally, Haridwar is suitable for medium and lower water polluting industries. The categorization of industries into high, medium and low water polluting industries is according to Central Pollution Control Board, New Delhi and Ministry of Environment, India (Geol, 1992; CPCB Report, 1997). Figure 9 and Table 5 shows that $2.94 \%$ of total area lies in the class (3/4) where environmental suitability is medium and economic suitability is high. This area is very suitable for medium water polluting industries like Synthetic Rubber, Bone Mills \& Allies Industries, Sugar, Pulp \& Paper (Waste Paper based), Fermentation (Malteries \& Breweries), Soft Drinks, Fruit \& Vegetables Processing, Fibre 
Board Manufacturing, Natural Rubber, Paper Board, Biscuit Production, Jute Processing, Dairy, Soap (Detergent Formulation). Again, $8.57 \%$ area is suitable for medium polluting industries where environmental and economic suitability are equal. About $21.8 \%(14.96+6.84 \%)$ of the area lie in the class which is suitable for medium water polluting industries but economic suitability is low which means if accessibility and infrastructure is provided then this area will be suitable for medium water polluting industries. About $7.58 \%(2.01 \%+$ 5.57 ) of the total area has low environmental suitability and good economic suitability which means this area is very suitable of low water polluting industries like Small Scale Industries, Cement, Stone Crushing, Carbon Black, Asbestos Manufacturing, Re-Heating (Reverberatory) Furnace, Foundries, Small Boilers, Glass, Lime Kiln, Ceramic, Small Boilers, Glass, Pottery \& Earthen Ware, Meat Processing, Soft Drinks (Fruit based Synthetic), Bread Bakery, Confectioneries. About $16.46 \%$ of the area is suitable for low water polluting industries but is requires accessibility and infrastructure development. Areas which are suitable for medium water polluting industries are also suitable for low water polluting industries. $36.91 \%$ of total area is not suitable for industrial siting as it is environmentally sensitive area which comes under constrains.

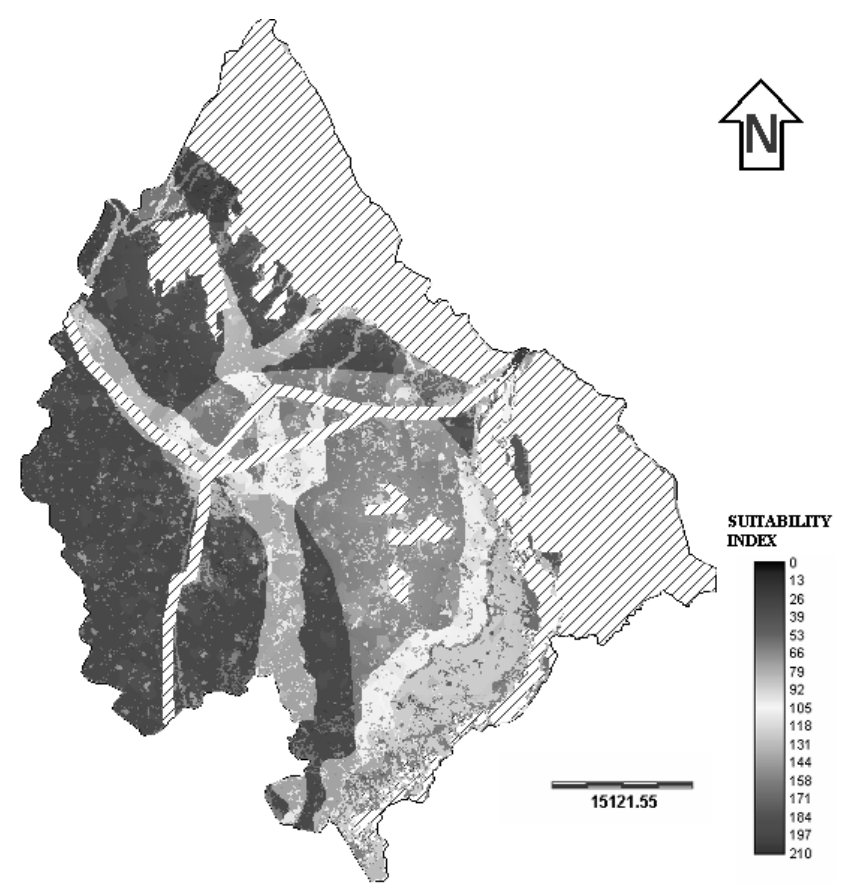

Figure 4. Environmental suitability index map.

The results show that highly suitable area for industrial siting is very negligible, when environmental factors are considered. The socio-economic suitability depicts $5.04 \%$ of highly suitable area. This is may be due to the contribution of national highways proximity layer as it have maximum weight of 0.3296 . If decision makers give priority to socioeconomic factors then this $5.04 \%$ area will be demarked as suitable for industrial siting. This area lies within or closer to city like Roorkee and Haridwar which are growing cities.
Therefore, the installation of any industry without knowing its environmental impact can risk human health and the environment in the long term. The cross tabulation result implies that this area is suitable for low and medium groundwater polluting industries as it lies in class $2 / 4$ and $3 / 4$ (Figure 8). About $44.9 \%$ of medium environmental suitable area has low socio-economic suitability. Therefore, if infrastructure facilities are provided to this area then it can be used for siting low to medium groundwater polluting industries.

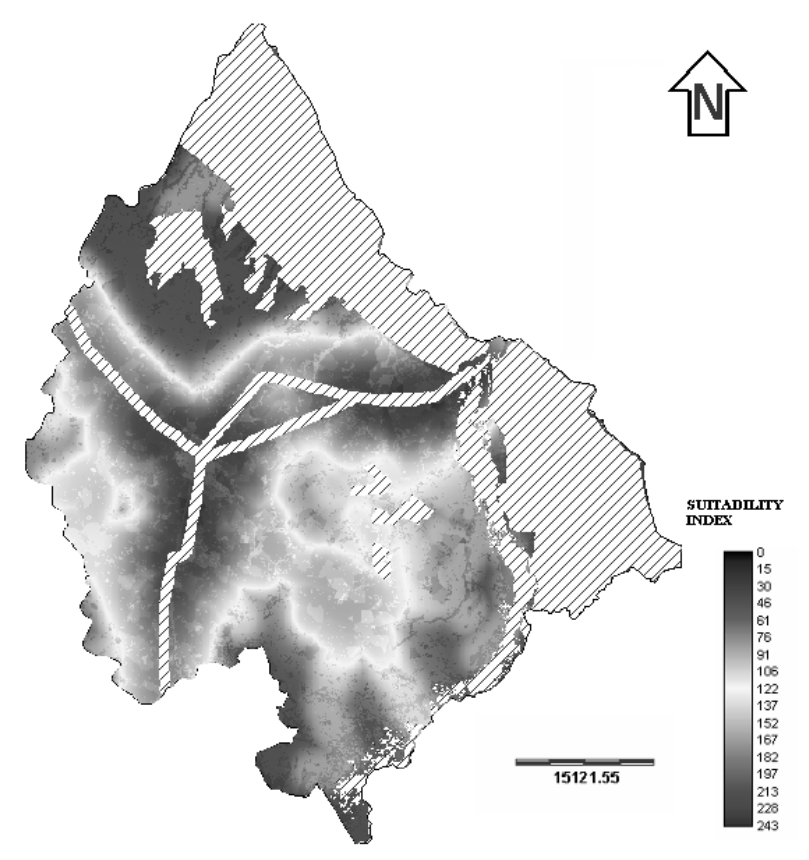

Figure 5. Economic suitability index map.

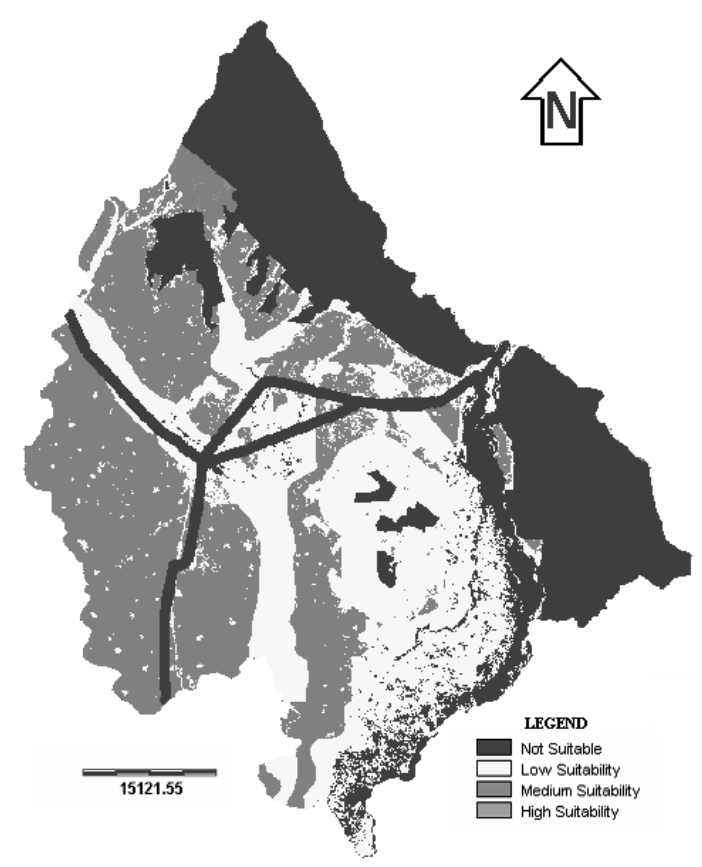

Figure 6. Reclassified environmental suitability. 


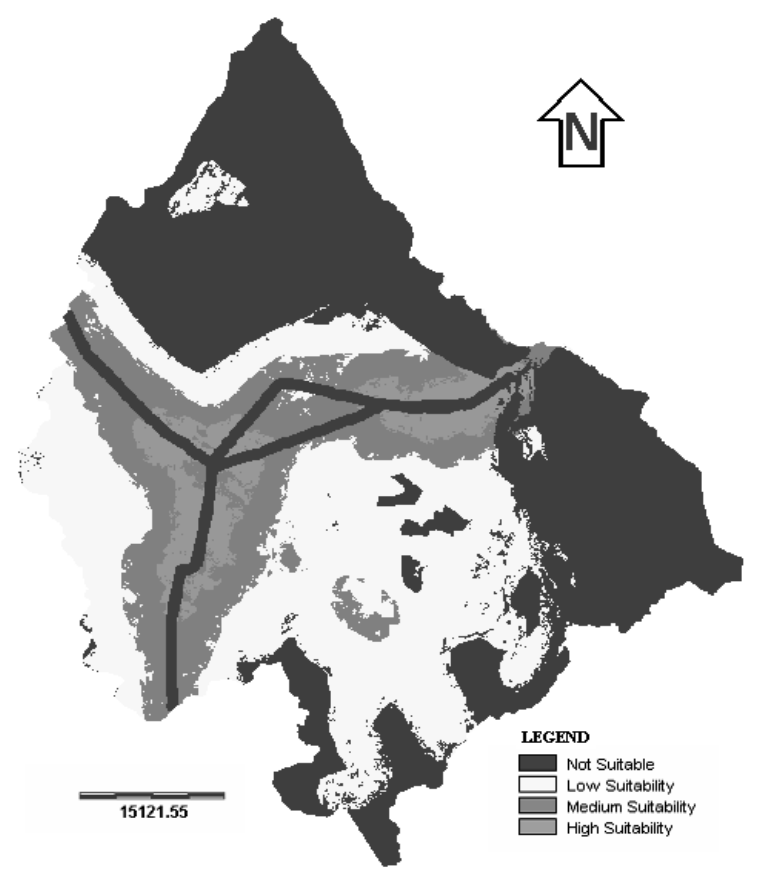

Figure 7. Reclassified economic suitability.

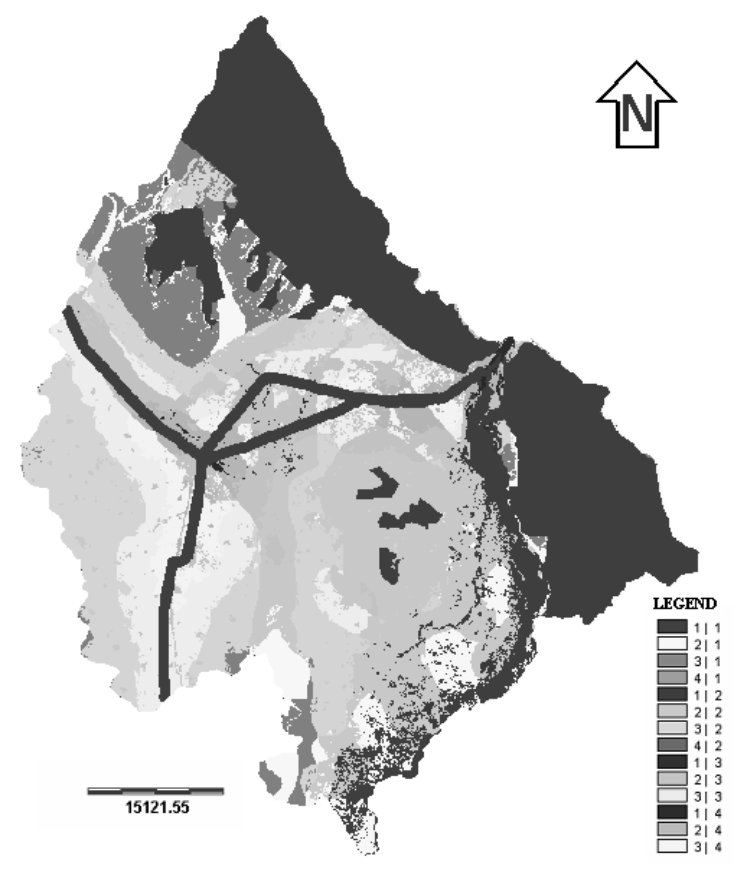

Figure 8. Final suitability map.

\section{Conclusions}

Finally, the result shows that the study area is suitable for medium and low water polluting industries and is not suitable for heavy water polluting industries. $36.91 \%$ of area is unsuitable for industrial siting. An attempt is made to identify the most appropriate spatial pattern for siting various groundwater industries at regional scale which can be used in early stages of planning and management. It is concluded that this metho- dology can be utilized by the planners and decision makers who often have to make complex decisions within a short period of time. The combination of GIS and multicriteria decision making can be a powerful tool for preliminary Environmental Impact Assessment for siting industries. It would be better to mention that detailed feasibility study should be done on the selected industrial site at local level so that it verifies that the industry is imparting minimum environmental pollution and contamination risks. The sensitivity of criterion weights requires further investigation.

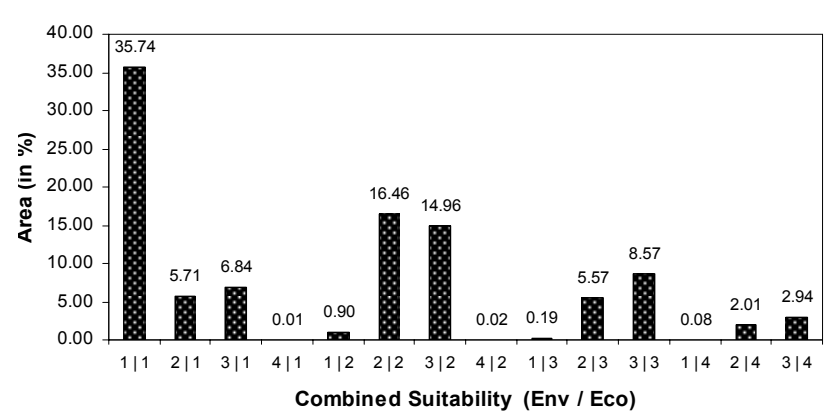

Figure 9. Graph showing percentage area in each class of final suitability map.

Table 6. Summary of Final Suitability Map

\begin{tabular}{lll}
\hline Class (Env. / Eco.) & Area (km sq.) & Area (\%) \\
\hline $1 / 1$ & 831.21 & 35.74 \\
$2 / 1$ & 132.76 & 5.71 \\
$3 / 1$ & 159.11 & 6.84 \\
$4 / 1$ & 0.15 & 0.01 \\
$1 / 2$ & 20.88 & 0.90 \\
$2 / 2$ & 382.83 & 16.46 \\
$3 / 2$ & 347.99 & 14.96 \\
$4 / 2$ & 0.53 & 0.02 \\
$1 / 3$ & 4.40 & 0.19 \\
$2 / 3$ & 129.46 & 5.57 \\
$3 / 3$ & 199.37 & 8.57 \\
$1 / 4$ & 1.98 & 0.08 \\
$2 / 4$ & 46.86 & 2.01 \\
$3 / 4$ & 68.34 & 2.94 \\
Total Area & 2325.87 & 100 \\
\hline
\end{tabular}

Table 7. Environmental Impact Score and Suitability Classes

\begin{tabular}{llll}
\hline EIS $^{*}$ & Industry Polluting & SIV & Suitability \\
\hline 3 & Low & $78-153$ & Low \\
6 & Medium & $154-204$ & Medium \\
8 & High & $205-255$ & High \\
\hline
\end{tabular}

*EIS: Environment Impact Score; SIV: Suitability Index Value

\section{References}

Agarwal, C.S., Malhotra, S.K., Rao, M.S. and Srivastava, S.S. (2000). Hydrological study of district-Haridwar \& Saharnpur (Interim Report), A collaborative Study with National Institute of Hydrology-Roorkee, Tm.No.1 Hyd (R-1), Ground Water Department, U.P.

Agarwal, S.K. (1996). Industrial Environment (Assessment and Strategy), APH Publishing Corporation, New Delhi. 
Burden, D.S. and Sims, J.L. (1999). Ground Water Issue - Fundamentals of soil science as applicable to management of hazardous wastes, EPA/540/S-98/500. http://www.p2pays.org/ref/12/12869.p df.

Canter, L.W. (1996). Environmental Impact Assessment, Mc GrawHill, pp. 248-302.

Carver, S.J. (1991). Integrating multi-criteria evaluation with geographical information systems, International Journal of Geographical Information Systems, 5(3), 321-339, doi:10.1016/0377-2217 (93) $90229-\mathrm{G})$.

C.P.C.B (Central Pollution Control Board, New Delhi) (1997). Zoning atlas for siting of industries (based on environmental considerations), EMAPS/8/1997-98 Environmental Planning and Mapping Series, C.P.C.B, New Delhi.

Collins, M.G., Steiner, F.R. and Rushman, M.J. (2001). Land-Use suitability analysis in the United States: historical development and promising technology achievements, Environ. Manage., 28 (5), 611-621, doi:10.1007/s002670010247.

Chakraborti, D., Samanta, G., Mandal, B.K., Chowdhury, T.R., Chanda ,C.R., Biswas, B.K., Dhar, R.K., Basu, G.K. and Saha, K.C. (1998). Calcutta's industrial pollution: groundwater arsenic contamination in a residential area and sufferings of people due to industrial effluent discharge - An eight-year study report, Curr. Sci., 74(4), 346-356.

Eastman J.R., Jin W., Kyem P.A.K. and Toledano J. (1995). Raster procedures for multicriteria/ multiobjective decisions, Photogramm. Eng. Remote Sensing, 61(5), 539-547

Eastman, J.R. (2003). IDRISI Kilimanjaro Guide to GIS and image processing, IDRISI Production, Clark Labs, pp. 145-190.

Geneletti, D. (2004). A GIS based decision support system to identify nature conservation priorities in an alpine valley, Land use Policy, 21(2), 149-160, doi:10.1016/j.landusepol.2003.09.005.

Geol, M.M. (1992). Industries \& Pollution Control (Policy, Procedure and Problems), Anupriya Publishing House, Jaipur, India.

Hussian, M. (2004). Assessment of groundwater vulnerability in an alluvial interface using GIS, unpublished $\mathrm{PhD}$ thesis, Department of Hydrology, IIT- Roorkee.

Inyang, H., Fisher, G. and Mbamalu, G.E. (2003). A quantitative methodology for indexing environmental sensitivity and pollution potential, Environmental Monitoring and Assessment, 84, 159-173.

Jagannadha, S.V.V. and Swamy, A.N. (1986). Delineation of chemically polluted groundwater regions in Visakhapatnam basin, India, Water, Air, and Soil Pollution, 29, 15-26.

Jenson, J.R. (2004). Remote Sensing of the Environment - An Earth Resource Perspective, Second Indian Reprint, Pearson Education (Singapore) Pte ltd., New Delhi.

Jiang, H. and Eastman, J.R. (2000). Application of fuzzy measures in multi-criteria evaluation in GIS, Int. J. Geogr. Inf. Sci., 14(2), 173184, doi:10.1016/S0096-3003(95)00218-9.

Joerin, F., Thetiault, M. and Musy, A. (2001). Using GIS and outranking multicriteria analysis for land-use suitability assessment, Int. J. Geogr. Inf. Sci., 15(2), 153-174.

Kaplay, R.D. and Patode, H.S. (2004). Groundwater pollution due to industrial effluent at Tuppa, New Nanded, Maharashtra, India, Environ. Geol., 46(6-7), 871-882, doi:10.1007/s00254-004-1095$\mathrm{z}$.

Lillisand, T.M. and Kiefer, R.W. (2000). Remote Sensing and Image Interpretation, Fourth edition, John Wiley \& Sons Inc.

Lindenmayer, D.B. (1999). Future directions for biodiversity conservation in managed forests: indicator species, impact studies and monitoring programs, Forest Ecology and Management, 115: 277-287, doi:10.1016/S0378-1127 (98)00406-X.

Lwasa, S.A. (2005) Geo-information approach for Urban Land use Planning in Kampala, Pharaohs to Geoinformatics FIG Working
Week 2005 and GSDI-8" Cairo, Egypt April 16-21, 2005. http:// www.fig.net/pub/cairo/papers/ts_37/ts37_03_lwasa.pdf.

Malczewski, J. (1999). GIS and Multi-criteria Decision Analysis, New York, John Wiley \& sons, Inc.

Malczewski, J. (2004). GIS based land-use suitability analysis: a critical overview, Progress in Planning, 62(1), 3-65, doi:10.1016/ j.progress.2003.09.002.

Malczewski, J. (2006). GIS based multicriteria decision analysis: a survey of the literature, Int. J. Geogr. Inf. Sci., 20(7), 703-726, doi:10.1080/13658810600661508.

McHarg, I. (1969). Design with nature, Natural History Press, New York, pp.197.

Mendoza, G.A. (1997). GIS-based multicriteria approaches to land use suitability assessment and allocation, Seventh Symposium on Systems Analysis in Forest Resources. http://www.ncrs.fs.fed. us/pubs/gtr/other/gtr-nc205/pdffiles/p31.pdf (Last accessed date: 30th Oct.2006).

Mondal, N.C., Saxena, V.K. and Singh, V.S. (2005). Assessment of groundwater pollution due to tannery industries in and around Dindigul, Tamilnadu, India, Environ. Geol., 48(2), 149-157, doi: 10.1007/s00254-005-1244-z.

Morries, A. and Jankowski, P. (2001). Fuzzy techniques for multiple criteria decision making in GIS, IFSA World Congress and 20th NAFIPS International Conference, 4, 2376-2381. http://ieeexplo re.ieee.org/iel5/7506/20436/00944444.pdf (Last accessed date 8th Nov.2006)

Olayinka, K.O. (2004). Studies on industrial pollution in Nigeria: the effect of textile effluents on the quality of groundwater on some parts of Lagos, Nigerian Journal of Health and Biomedical Science, 3(1), 44-50.

Reza B.K. (1989). New method for site suitability analysis: The Analytic Hierarchy Process, Environ. Manage., 13(6), 685-693, doi:10.1007/BF01868308.

Satyanarayana, S., Gupta, S.K., Eldho, T.I. and Gurunadha, R.V.V.S. (2005). Degradation of groundwater quality - A case study on Industrial pollution, XII World Water Congress for Sustainable Development-Towards Innovative Solutions, 22-25th Nov.2005, New Delhi, India.

Siddiqui, M., Everett, J. and Vieux, B. (1996). Landfill siting using geographic information system: a demonstration, J. Environ. Eng., 122(6), 515-523, doi:10.1061/(ASCE)0733-9372(1996)122:6(515).

Simsek, C., Kincal, C. and Gunduz, O. (2006). A solid waste disposal site selection procedure based on groundwater vulnerability mapping, Environ. Geol., 49(4), 620-633, doi:10.1007/s00254-005-01 $11-2$.

Singhal, B.B.S. (2002). Groundwater Resource of India. International Association of Hydrogeologists Austrialian National Chapter's International Groundwater conference proceeding, Balancing the groundwater budget, Darwin, 12 -17 May 2002 Northern Territory, Australia.

Stoms, D.M., McDonald, J.M. and Davis F.W (2002). Fuzzy Assessment of Land Suitability for Scientific Research Reserves, Environ. Manage., 29(4), 545-558, doi:10.1007/s00267-001-0004-4.

Strong, W.R. (1988). The Shoals Industrial Development Information System, GIS/LIS'88 Third annual International Conference Nov. 30-Dec2, 1998 San Antonio, Texas Proceedings, 2, 490-497.

Subba Rao, N., Gurunadha Rao, V.V.S. and Gupta, C.P. (1998). Groundwater pollution due to discharge of industrial effluents in Venkatapuram area, Visakhapatnam, Andhra Pradesh, India, Environ. Geol., 33(4), 289-294, doi:10.1007/s002540050248.

Thomas, M.R. (2002). A GIS-based decision support system for Brownfield redevelopment, Landscape Urban Plann., 58, 7-23, doi:10.1016/S0169-2046(01)00229-8. 